\title{
On the Ethics of "Non-Corporate" Insider Trading
}

\author{
Benjamin M. Blau' ${ }^{1}$ Todd G. Griffith ${ }^{1} \cdot$ Ryan J. Whitby ${ }^{1}$
}

Received: 22 April 2020 / Accepted: 7 January 2021 / Published online: 17 February 2021

(c) The Author(s), under exclusive licence to Springer Nature B.V. part of Springer Nature 2021

\begin{abstract}
The ethical considerations of insider trading have been widely debated in the academic literature (see e.g., Moore in J Bus Ethics 9(3):171-182, 1990). In 2013, the STOCK Act, which was initially passed to mitigate insider trading by government officials, was quickly and unexpectedly amended to allow certain government employees to withhold their financial information. To identify and quantify the potential costs placed on investors by non-corporate insider traders, we use the unusual circumstances surrounding this amendment. For a sample of stocks most held by members of Congress, we find that, relative to control stocks, liquidity significantly worsens and volatility increases during the post-amendment period. Our results highlight the costs that are incurred by investors in the presence of non-corporate insider trading. These findings call for a stronger development of an ethical framework that justifies the restriction of all types of insider trading.
\end{abstract}

Keywords Insider trading $\cdot$ Market quality $\cdot$ Insider trading laws $\cdot$ STOCK Act $\cdot$ Corruption

\section{Introduction}

The ethical considerations of insider trading, and the economic costs and benefits associated with laws prohibiting insider trading, have been widely debated in the academic literature. For example, Brudney (1979) argues that, under the Securities and Exchange Act of 1934, the prohibition of insider trading is justified because it presents an "unfair" informational advantage for insiders relative to outsiders. The author states, "the unfairness is not a function merely of possessing more information—outsiders may possess more

Benjamin M. Blau

ben.blau@usu.edu

Todd G. Griffith

todd.griffith@usu.edu

Ryan J. Whitby

ryan.whitby@usu.edu

1 Department of Economics and Finance, Jon M. Huntsman School of Business, Utah State University, 3565 Old Main Hill, Logan, UT 84322, USA information than other outsiders by reason of their diligence or zeal-but of the fact that it is an advantage which cannot be competed away since it depends upon a lawful privilege to which an outsider cannot acquire access." Other studies, however, have argued that the idea of "fairness" is ambiguous and certain economic tradeoffs, such as price efficiency, exist that might justify the presence of insider trading (e.g. Leland 1992; Ma and Sun (1998)). ${ }^{1}$

Since government officials, such as members of Congress, make policy decisions that directly affect corporate profitability, they often possess valuable information that

\footnotetext{
${ }^{1}$ Several studies highlight that insider trading resolves uncertainty about the value of firms and leads to security prices that are more informationally efficient - or prices that fully reflect relevant information (see Manove 1989; Ausubel 1990; Seyhun 1992; Allen and Gale 1992; Benabou and Laroque 1992; and Bhattacharya and Nicodano 2001). Martin and Peterson (1991) use the price efficiency improvements noted above to make an ethical argument that supports insider trading.
} 
is unknown to the public. ${ }^{2}$ In fact, Ziobrowski et al. (2004, 2011) show that U.S. Senators trade with a significant informational advantage - stock prices increase around Senate purchases and level off around sales. More specifically, portfolios that mimic U.S. Senators and members of the U.S. House of Representatives beat the market by approximately 85 and 55 basis points per month, respectively. For comparison, Jeng et al. (2003) show that portfolios that mimic the trades of actual corporate insiders earn an abnormal return of only 40 basis points per month. Recent media reports have even highlighted the stock selling of certain members of the U.S. Congress before the onset of the sharp decline in financial markets due to the coronavirus pandemic. ${ }^{3}$ These reports have attempted to link these congressional stock trades to private access to information about the U.S. government's response to the coronavirus outbreak. Jack Kelly, a senior contributor at Forbes Magazine published the following on March 20, 2020,

Our elected officials in Congress are supposed to look out for our best interests. In a shocking revelation, it's been reported that a number of senators sold their stock holdings after being briefed about the coronavirus and the massive impact it will have upon the economy, jobs and the stock market. While telling the American public that there wasn't much to worry about, they bailed out of their stock holdings to avoid large losses. ${ }^{4}$

We contend that insider trading by government officials has the potential to violate all four ethical arguments outlined in Moore (1990), i.e. unfairness, harmful practice, violation of property rights, and disruption of fiduciary relationships. Since not all market participants are privy to the same information, and no amount of legal due diligence could allow an outside investor to obtain the information, it can create an unfair informational advantage for government officials. If that information is then exploited at the expense of ordinary investors who transact with insider government officials, then the practice may also be deemed harmful and erode investor confidence. While these arguments of

\footnotetext{
2 Ahmed et al. (2010) show that the net realized costs associated with the Sarbanes Oxley Act amount to roughly $\$ 19$ billion per year for their sample firms.

3 Additional articles regarding this matter are available at https:// www.politico.com/news/2020/03/21/coronavirus-trading-house-senat e-140260 and https://www.marketwatch.com/story/two-senators-areunder-fire-for-selling-stock-before-the-coronavirus-market-crash-butdo-insider-trading-laws-apply-2020-03-20.

${ }^{4}$ Forbes article, "Senators Accused of Insider Trading, Dumping Stocks After Coronavirus Briefing" is available at: https://www.forbe s.com/sites/jackkelly/2020/03/20/senators-accused-of-insider-tradingdumping-stocks-after-coronavirus-briefings/?sh=ee85b0e4a $45 \mathrm{~d}$.
}

unfairness and harm may have merit, particularly in the anecdote outlined above, to the courts, insider trading is more about how the information is acquired and what entitles a person to make use of the information. If information is property, and that property belongs to a firm, then government officials who trade on non-public information more generally might violate the firm's property rights. Moore (1990) contends that the most compelling argument against insider trading is that it undermines the fiduciary relationships between the firm, its employees, and its shareholders. The perception of insider trading by government officials not only has the potential to create distrust between shareholders but also between the firm and its shareholders. Moreover, elected officials, and those employed by the government, have a fiduciary duty to the general public, some of which are shareholders, as well as to the office that they hold.

Studies have shown that transaction costs increase in the presence of insider trading because liquidity providers will widen bid-ask spreads to be compensated for trading in an environment that is wrought with asymmetric information (Copeland and Galai 1983; Kyle 1985; Glosten and Milgrom 1985; Barclay and Smith 1988; Bettis et al. 2000; Brockman and Chung 2001; Du and Wei 2004). Additionally, other studies have argued that insider trading creates an incentive to manipulate the timing and content of information releases (Ausubel 1990; Allen and Gale 1992), both of which can induce volatility in stock prices (see e.g., Du and Wei 2004 for empirical evidence). Thus, if government officials have an informational advantage, it can directly lead to financial losses for ordinary shareholders through higher trading costs and unstable prices.

In this study, we examine the market quality consequences associated with non-corporate insider trading. Many laws have limited or restricted the trading of employees and executives of public companies. However, until the "Stop Trading on Congressional Knowledge" (STOCK) Act in 2012, The Senate Code of Official Conduct did not place any restrictions on stock trading by members of the U.S. Senate. Similarly, The Ethics Manual for Members, Officers, and Employees of the U.S. House of Representatives did not provide trading restrictions to members of the U.S. House. The general intention of the STOCK Act, which was signed into law on April 4th, 2012, was to increase the transparency of the personal financial dealings of high-ranking federal employees by requiring greater disclosure about securities transactions. Initially, the disclosure requirements extended to all employees and members of Congress, as well as their staffers. Unexpectedly, however, the STOCK Act was amended on April 15th, 2013 by Senate Bill 716, which relaxed the disclosure requirements for both employees and staffers. The bill was unanimously advanced by the U.S. Senate without debate or discussion on April 11th, 2013. The U.S. House passed the bill in a similar manner on April 
12th. President Barack Obama signed the bill into law on Monday, April 15th, 2013. So, within 4 days and with almost no publicity, parts of the STOCK Act were amended that allowed some individuals within the government to trade on possible inside information. ${ }^{5}$

Unlike the passage of the original STOCK Act, which was debated and discussed for approximately 2 months before being signed into law, the unexpected amendment of the act provides a unique opportunity for researchers to isolate the effect of perceived insider trading by government employees on the quality of financial markets. In the context of the ethical framework of insider trading, the amendment allows researchers to identify the potential harm to outsiders caused by the presence of "non-corporate" insider trading. Therefore, the objective of our study is twofold. First, we attempt to quantify the harmful effects of the amendment on the quality of financial markets. Second, we provide a discussion that broaches the notion of non-corporate insider trading in the ethical considerations that exist in the current literature.

The results from our tests suggest that, relative to control stocks, the stocks that were most widely held by members of Congress became less liquid and more volatile in the 20 days following the amendment. These results are consistent with the theoretical predictions that the presence of insider trading can increase both adverse selection and trading costs (Copeland and Galai 1983; Kyle 1985; Glosten and Milgrom 1985). Our results also align with the theoretical perspective that insider trading can destabilize stock prices (Manove 1989; Ausubel 1990; Allen and Gale 1992; Benabou and Laroque 1992; Leland 1992; Bhattacharya and Nicodano 2001). However, instead of exploring trading by insiders of the firm, our results contribute to the extant literature by focusing on non-corporate insider trading.

In economic terms, our multivariate tests show that, relative to control stocks, the bid-ask spreads of treatment stocks increase between 3.1 and 4.3 percentage points after the amendment. We also find that quoted depth decreases by approximately 17 percent. Furthermore, we find that adverse selection costs increase between 5.4 and 7 percentage points. When examining the volatility of stocks surrounding the amendment to the STOCK Act using a Garch $(1,1)$ approach, we find that return volatility increases by about 3 percentage

\footnotetext{
5 There exists anecdotal evidence that congressional staffers also engage in the trading of securities while possessing non-public information. While data regarding the trading behavior of staffers is unavailable, the anecdotes seem to suggest that congressional aids and staffers might also benefit financially from trading on non-public information. See, for example, https://www.wsj.com/articles/SB100 01424052748703431604575522434188603198. https://www.politico. com/story/2017/09/25/congress-aides-stock-market-trades-investment s-analysis-242692.
}

points after the amendment for treated stocks compared to control stocks. When measuring volatility using the rangebased stochastic measure of Alizadeh et al. (2002), we find that the volatility of prices increases slightly more than 8 percentage points. These findings seem to indicate that the perception of trading by government insiders both harms market quality and destabilizes stock prices.

Our findings have important implications regarding the debate about the ethics of insider trading. First, we find that insider trading by non-corporate insiders imposes costs on ordinary investors in the form of illiquidity and volatility. These findings-particularly the increase in volatility-questions the notion that insider trading has positive economic tradeoffs relating to market efficiency (Manove 1989; Ausubel 1990; Martin and Peterson 1991; Seyhun 1992; Allen and Gale 1992; Benabou and Laroque 1992; Bhattacharya and Nicodano 2001). Furthermore, our results run contrary to arguments about the improved price stability associated with insider trading discussed in Manne (1966), Lin and Rozeff (1995), and Smith and Block (2016). Second, our results contribute to the ethical discussion regarding the legislating of insider trading. The increase in trading costs, adverse selection costs, and volatility around the relaxation of insider trading laws lend direct support for the unfairness, harmfulness, and distrust ethical arguments made by Moore (1990). Thus, it appears that more stringent restrictions on non-corporate insiders might be considered-particularly for elected government officials who are supposed to look out for the public's best interests.

The rest of the paper follows. "Details of the STOCK Act" section discusses the detail of the STOCK Act and the amendment. "Data Description" section describes the data used throughout the analysis. "Empirical Results" section presents the results from our empirical test. "A Discussion on the Ethical Implications of Our Results" section offers a discussion about the ethical implications of our empirical results. "Concluding Remarks" section presents some concluding remarks.

\section{Details of the STOCK Act}

The STOCK Act (Senate Bill 2038), which was signed into law by President Barack Obama on April 4th, 2012, was initially introduced by Senator Joseph Lieberman on January 26th, 2012, and made its way through both the Senate and House with large majority support in both chambers of Congress. The bill was intended to prohibit members and employees of Congress to benefit financially from holding privileged information. In particular, securities transactions, which had previously been reported annually, were required to be disclosed within 45 days of the transaction. Additional disclosure requirements were also required for 
the real estate holdings of government officials and employees. Perhaps most importantly, "Empirical Results" section of the bill declared that both members and employees of Congress must abide by insider trading prohibitions stated in the Securities and Exchange Act of 1934 and Rule 10b-5. This restriction was new. For instance, while the U.S. Senate Ethics Manual prohibited "individuals from using their legislative power to advance their financial interests (Paragraph 4 of Rule 37)", the manual states that "Legislation may have a significant financial effect on a Senator because his holdings are involved, but if the legislation also has a broad, general impact on his state or the nation, the prohibitions of the paragraph would not apply." ${ }^{\prime 6}$ Later, the ethics manual states, "The strong presumption would be that the Member [of the Senate] was working on legislation because of the public interest and the needs of his constituents and that his financial interest was only incidentally related...(Pg. 69)."

Recognizing the ambiguity associated with the direction provided in the Senate Ethics Manual, the STOCK Act strictly focused on securities trading and amended the Securities and Exchange Act of 1934 by requiring greater disclosure of the investment activity by members and employees of Congress. In March 2013, the National Academy of Public Administration conducted and submitted an independent review to President Obama and Congress that outlined how personal financial disclosures of lawmakers, their legislative staffs, and other executive branch officials could raise national security concerns. ${ }^{7}$ The review stated that such disclosures could result in "negative outcomes to the missions of national security and law enforcement agencies and their staff members (Pg. 56)."

On Thursday, April 11th, 2013, Senate Bill 716 was introduced and passed with unanimous consent after three readings. The following day, the House of Representatives passed the bill without debate, thus sending the bill to the President's desk. On Monday, April 15th, 2013, President Obama signed the bill overhauling the disclosure requirements by anyone other than the President or members of Congress. The details of how the initial STOCK Act was passed, and later amended, are important, given that we use the amendment date as part of our identification strategy. The reason we do not use the passage of the initial STOCK Act as an exogenous shock to the enforcement of insider trading laws is that the initial passage of the bill stretched out over 2 months. It, therefore, becomes difficult to isolate the effect of the STOCK Act passage on the quality of financial markets. In contrast, the amendment to the STOCK Act is arguably exogenous and occurred over a much shorter 3-day

\footnotetext{
${ }_{6}$ See http://www.ethics.senate.gov/downloads/pdffiles/manual.pdf.

${ }^{7}$ See http://www.napawash.org/wp-content/uploads/2013/03/STOCK actFinal1.pdf.
}

period. Because of these differences, our tests regarding the effect of non-corporate insider trading on financial market quality is best suited for the amendment to the STOCK Act instead of the initial passage of the law.

\section{Data Description}

The data used in the analysis come from two sources. First, from the Center for Research and Security Prices (CRSP), we gather daily stock returns, closing prices, high and low prices, shares outstanding, and share volume for the universe of stocks. We require the stocks to have an average closing price greater than $\$ 5$ and less than $\$ 1000$. From the NYSE Trade and Quote (TAQ) database, we obtain intraday quotes and trade prices as well as quoted depth. To isolate the effect of the STOCK Act modification on the quality of markets, we examine the 41 days surrounding the passage of the amendment, which occurred on April 15th, 2013 (March 15th, 2013 to May 13th, 2013). ${ }^{8}$ However, changes in market quality might have occurred for reasons unrelated to the amendment. For instance, other events, like the Boston Marathon bombing, which occurred at the same time as the amendment, might confound our tests. To account for this possibility, we need to identify the stocks that are most likely to be affected by the law change. To do so, we obtain the 50 securities that have the highest Congressional holdings from the Center for Responsive Politics (CRP), which is the third source of our data. ${ }^{9}$ We identify this subsample of stocks as our treatment group. The CRP data only includes the names of the 50 securities that are most widely held by members of congress. Unfortunately, the CRP data does not include the number of shares, the identities of the owners, or the market value of the holdings, which would allow us to be more precise with our empirical tests. The remaining stocks on CRSP are used as the control group. The purpose of including the remaining CRSP stocks as a control group is that we can only identify the most widely held stocks by members of Congress using the CRP data. ${ }^{10}$ Admittedly,

\footnotetext{
$\overline{8}$ Our results are robust to various event windows, such as 21-day, 61-day, and 91-day periods.

${ }^{9}$ Choosing the 50 stocks that were held by the most members of Congress is based on the public availability of data from the CRP. Also, we do not want to add to our treatment sample stocks that are held by only a few members of Congress.

${ }^{10}$ We note that data regarding the number of shares held by Congress is not widely available. We note, however, that for the purposes of our tests, the number of Congressional members holding the stock may be more relevant. For instance, the effect of the STOCK Act Amendment will likely affect the market quality of a stock held many members of Congress rather than a stock held by only a few members of Congress-even if the total percent of shares outstanding held is lower for the former vis-à-vis the latter.
} 
Table 1 Treatment sample of stocks with highest level of Congressional holdings

\begin{tabular}{|c|c|c|c|c|}
\hline $\begin{array}{l}\text { Ticker } \\
{[1]}\end{array}$ & $\begin{array}{l}\text { Company name } \\
{[2]}\end{array}$ & $\begin{array}{l}\text { All Congress } \\
{[3]}\end{array}$ & $\begin{array}{l}\text { Democrats } \\
{[4]}\end{array}$ & $\begin{array}{l}\text { Republicans } \\
{[5]}\end{array}$ \\
\hline GE & General Electric & 84 & 38 & 45 \\
\hline PG & Proctor and Gamble & 69 & 31 & 37 \\
\hline MSFT & Microsoft & 65 & 32 & 33 \\
\hline WFC & Wells Fargo & 63 & 28 & 35 \\
\hline AAPL & Apple & 62 & 30 & 31 \\
\hline XOM & Exxon Mobil & 55 & 18 & 36 \\
\hline JPM & JP Morgan & 55 & 24 & 31 \\
\hline $\mathrm{CSCO}$ & Cisco & 52 & 22 & 29 \\
\hline INTL & Intel & 50 & 25 & 25 \\
\hline $\mathrm{T}$ & AT\&T & 49 & 15 & 34 \\
\hline JNJ & Johnson and Johnson & 49 & 19 & 29 \\
\hline IBM & International Business Machines & 48 & 21 & 26 \\
\hline PFE & Pfizer & 47 & 19 & 28 \\
\hline PEP & PepsiCo & 46 & 20 & 25 \\
\hline KO & Coca-Cola & 46 & 19 & 27 \\
\hline $\mathrm{CVX}$ & Chevron & 45 & 17 & 28 \\
\hline $\mathrm{VZ}$ & Verizon & 43 & 16 & 27 \\
\hline BAC & Bank of America & 41 & 16 & 25 \\
\hline DIS & Disney & 40 & 23 & 16 \\
\hline MCD & McDonalds & 40 & 18 & 22 \\
\hline QCOM & Qualcomm & 38 & 17 & 20 \\
\hline GLD & SPDR Gold Trust & 37 & 14 & 22 \\
\hline MRK & Merck \& Co. & 33 & 11 & 22 \\
\hline MMM & $3 \mathrm{M}$ & 32 & 15 & 16 \\
\hline BRK.A & Berkshire Hathaway & 31 & 13 & 18 \\
\hline WMT & Walmart & 30 & 12 & 18 \\
\hline CMCSA & Comcast & 29 & 14 & 15 \\
\hline $\mathrm{ABT}$ & Abbott Laboratories & 29 & 9 & 20 \\
\hline HD & Home Depot & 29 & 13 & 16 \\
\hline GOOG & Google & 29 & 10 & 18 \\
\hline BMY & Bristol-Myers Squibb & 28 & 11 & 17 \\
\hline UTX & United Technologies & 28 & 11 & 16 \\
\hline ORCL & Oracle & 28 & 11 & 16 \\
\hline VOD & Vodafone & 27 & 14 & 13 \\
\hline SLB & Schlumberger & 27 & 12 & 14 \\
\hline $\mathrm{C}$ & Citigroup & 27 & 12 & 15 \\
\hline EMC & EMC Corp & 25 & 10 & 14 \\
\hline AXP & American Express & 23 & 8 & 14 \\
\hline UNP & Union Pacific & 23 & 9 & 14 \\
\hline PM & Philip Morris International & 22 & 7 & 15 \\
\hline MDLZ & Mondelez International & 22 & 8 & 14 \\
\hline KMB & Kimberly Clark & 22 & 9 & 12 \\
\hline KRFT & Kraft Foods & 22 & 7 & 15 \\
\hline MO & Altria Group & 21 & 6 & 15 \\
\hline $\mathrm{COP}$ & ConocoPhillips & 21 & 6 & 15 \\
\hline ESRX & Express Scripts & 20 & 7 & 13 \\
\hline HP & Hewlett Packard & 20 & 6 & 14 \\
\hline $\mathrm{F}$ & Ford Motor & 19 & 8 & 11 \\
\hline $\mathrm{DD}$ & Du Pont & 19 & 6 & 13 \\
\hline AMZN & Amazon.com & 19 & 6 & 13 \\
\hline
\end{tabular}

The table reports the ticker symbols, the number of members of the U.S. Congress holding the particular stock, the number of Congressional Democrats holding the particular stock, and the number of Congressional Republicans holding the particular stock as of the end of 2012 
Table 2 Summary statistics

\begin{tabular}{llllll}
\hline & $\begin{array}{l}\text { Mean } \\
{[1]}\end{array}$ & $\begin{array}{l}\text { Std. Dev } \\
{[2]}\end{array}$ & $\begin{array}{l}\text { Minimum } \\
{[3]}\end{array}$ & $\begin{array}{l}\text { Median } \\
{[4]}\end{array}$ & $\begin{array}{l}\text { Maximum } \\
{[5]}\end{array}$ \\
\hline $\begin{array}{l}\text { \$ Effective } \\
\quad \text { Spread }\end{array}$ & 0.0175 & 0.0254 & 0.0073 & 0.0102 & 0.2175 \\
$\begin{array}{l}\text { \% Effective } \\
\text { Spread }\end{array}$ & 0.0003 & 0.0004 & 0.0001 & 0.0002 & 0.0041 \\
Ask Depth & 21,735 & 56,435 & 202 & 3,801 & 600,195 \\
Bid Depth & 21,714 & 56,276 & 199 & 3,802 & 508,737 \\
\$ Price Impact & 0.0086 & 0.0155 & -0.0180 & 0.0053 & 0.1595 \\
\% Price Impact & 0.0001 & 0.0001 & -0.0005 & 0.0001 & 0.0019 \\
Illiquidity & 0.0003 & 0.0029 & 0.0000 & 0.0000 & 0.0535 \\
Garch(1,1) & 0.0121 & 0.0035 & 0.0043 & 0.0114 & 0.0315 \\
Range Volatility & 0.0144 & 0.0068 & 0.0031 & 0.0130 & 0.0502 \\
Noise & 0.0071 & 0.0044 & 0.0000 & 0.0064 & 0.0371 \\
Price & 88.74 & 125.05 & 11.81 & 56.89 & 814.71 \\
MCAP & 131.29 & 89.73 & 0.32 & 111.30 & 435.33 \\
Turnover & 0.0064 & 0.0064 & 0.0010 & 0.0048 & 0.1371 \\
\hline
\end{tabular}

The table reports statistics that describe the sample of 49 securities most held by Congressional democrats and republicans during the 41-day window surrounding the STOCK act amendment on April 15, 2013. \$ Effective Spread on the $k$ th trade is defined as: $2 D_{k}\left(P_{k}-M_{k}\right)$, where $D_{k}$ is an indicator variable that equals +1 if the $k$ th trade is a buy and -1 if the $k$ th trade is a sell, $P_{k}$ is the price of the $k$ th trade (according to Lee and Ready 1991), and $M_{k}$ is the midpoint of the NBBO quotes assigned to the $k$ th trade. \% Effective Spread is the dollar effective spread scaled by the NBBO midpoint. Ask Depth is the number of shares available at the NBO at the time of the $k$ th trade. Bid Depth is the number of shares available at the NBB at the time of the $k$ th trade. \$ Price Impact on the $k$ th trade is defined as: $2 D_{k}\left(M_{k+5}-M_{k}\right)$, where $M_{k+5}$ is the midpoint 5-min after the midpoint $M_{k}$. \% Price Impact is the dollar price impact scaled by the NBBO midpoint. Illiq is Amihud's (2002) illiquidity measure defined as the absolute value of daily return divided by dollar volume, scaled by $10^{6}$. Garch Volatility is the volatility of stock returns obtained by fitting returns to a Garch $(1,1)$ model. Range Volatility is measured as the $\log$ of the daily high ask price minus the log of the daily low bid price. When an open price is greater (less) than the closing price, Noise is the sum of the difference between the intraday high price less the open price (closing price) and the closing price (opening price) less the intraday low price, scaled by the midpoint between the open price and the closing price. Price is the average daily closing price. $M C A P$ is the market capitalization, or price times shares outstanding (in $\$$ billions). Turnover is the daily number of shares traded over shares outstanding

there are stocks in the control sample that are also likely to be held by members of Congress. Including as many stocks as possible in the control group helps alleviate that problem so that the average or the median stock in the control group is not likely to be held by someone in Congress. In the analysis that follows, we use difference-in-difference tests to examine the change in the market quality measures of the treatment group compared to the control group, before and after the amendment.

Table 1 reports information about the treatment sample of stocks ranked by the number of Congressional holdings at the end of 2012. ${ }^{11}$ We note that to be included in the sample, stocks must have an average closing price of less than $\$ 1000$, which eliminates Berkshire Hathaway. During the sample period, Berkshire Hathaway had a closing price of $\$ 134,060$ per share at the end of 2012 and has unusually low levels of liquidity. Although the inclusion of Berkshire Hathaway does not influence our main findings from our multivariate tests, it does skew the summary statistics reported in Table 2 . To give a more accurate representation of our sample and to avoid confusion when using summary statistics to interpret multivariate results, we removed Berkshire Hathaway from our sample and analysis. Therefore, our treatment sample consists of the 49 stocks that were most widely held by members of Congress. Table 1 shows the breakdown of holdings by Democrats and Republicans in Congress. The majority of the stocks in the treatment sample are in the S\&P 500. General Electric has the most Congressional holdings as 84 members of Congress were shareholders of GE at the end of 2012. Amazon.com has the least number of Congressional ownerships in our treatment sample (19 members of Congress were shareholders of Amazon at the end of 2012). For the average treatment stock, roughly 37 members of Congress own shares (15 Democrats and 21 Republicans).

Table 2 provides statistics that summarize the treatment sample of 49 securities. To approximate the quality of financial markets we estimate a battery of market quality measures. First, we examine two measures of the round-trip cost to trade using the high-frequency TAQ database: the dollar effective spread on the $k$ th trade is defined as: $2 D_{k}\left(P_{k}-M_{k}\right)$, where $D_{k}$ is an indicator variable that equals +1 if the $k$ th trade is a buy and -1 if the $k$ th trade is a sell (trade direction is determined by the Lee and Ready 1991 algorithm), $P_{k}$ is the price of the $k$ th trade, and $M_{k}$ is the midpoint of the National Best Bid and Offer (NBBO) quotes assigned to the $k$ th trade. ${ }^{12}$ The relative effective spread is equal to the dollar effective spread scaled by the NBBO midpoint prevailing at the time of the $k$ th trade. We then average these intraday measures of the effective spread to the daily level by stock. The average dollar effective spread is $1.75 \phi$ with a standard deviation of $2.54 \phi$. The average relative effective spread is $0.03 \%$ with a standard deviation of $0.04 \%$.

Next, we estimate two measures of market depth, or shares available at the time of a given trade, using the NYSE TAQ database: Ask Depth is the total number of shares available at the National Best Offer (NBO) at the time of the $k$ th

\footnotetext{
11 There are only a few securities in the top 50 most held by Congress that change between 2012 and 2013.

12 We use the Lee and Ready (1991) algorithm to determine whether a given trade is a buy or sell. Under this convention, a trade is a buy when $P_{k}>M_{k}$, a sell when $P_{k}<M_{k}$, and the tick test is used when $P_{k}=M_{k}$. The tick test determines a trade is a buy (sell) if the most recent prior trade at a different price was at a lower (higher) price.
} 
trade. Bid Depth is the total number of shares available at the National Best Bid (NBB) at the time of the $k$ th trade. The quoted depth is the sum of the ask depth and bid depth. We average the depth measures by stock over the trading day. For the average trade, we find that the quotes are fairly balanced, with 21,735 shares on the offer side and 21,714 shares on the bid side. This implies that, on average, for a treatment stock in the sample, there are over 43,000 shares available at the NBBO. However, at the extreme, we show that the average number of shares on the ask side is as high as 600,195 and only 508,737 on the bid side.

Our next set of measures approximate the losses to liquidity demanders due to adverse selection. We follow Hendershott et al. (2011), among others, and estimate the 5-min dollar price impact of the $k$ th trade as $2 D_{k}\left(M_{k+5}-M_{k}\right)$, where $D_{k}$ is an indicator variable that equals +1 if the $k$ th trade is a buy and -1 if the $k$ th trade is a sell (trade direction is determined by the Lee and Ready 1991 algorithm), and $M_{k+5}$ is the NBBO midpoint 5-min after the midpoint $M_{k}$. The relative price impact is the dollar price impact scaled by the NBBO midpoint at the time of the $k$ th trade. We also estimate a low-frequency proxy of the adverse selection component of the spread using the CRSP database. Following Amihud (2002), we estimate illiquidity as the absolute value of the daily return divided by daily dollar volume (scaled $10^{6}$ ). Goyenko et al. (2009) show that this illiquidity proxy is closely related to intraday relative price impact. Table 2 shows that the average dollar price impact on a treatment stock trade is $\$ 0.0086$ with a maximum of $\$ 0.1595$. The average relative price impact is $0.01 \%$, with a standard deviation of $0.01 \%$. Similarly, the average relative illiquidity is $0.03 \%$.

Our final set of market quality measures attempt to capture the volatility and stability of security prices. We estimate the following two volatility measures using daily CRSP data: $\operatorname{GARCH}(1,1)$ is obtained by estimating the following equation for each stock:

$\sigma_{t}^{2}=\eta V_{L}+\alpha \mu_{t-1}^{2}+\beta \sigma_{t-1}^{2}$,

where $V_{L}$ is the long-run variance, $\sigma_{t-1}^{2}$ is the prior day's volatility of returns, and $\mu_{t-1}^{2}$ is the volatility of the residual returns. We empirically estimate the equation parametrically in the following way:

$\sigma_{t}^{2}=\omega+\alpha \mu_{t-1}^{2}+\beta \sigma_{t-1}^{2}$.

The outcome of this estimation yields parameters for $\omega, \alpha$, and $\beta$. We can transform these parameters to obtain the long-run variance, $\operatorname{GARCH}(1,1)$, which is the standard deviation of the long-run variance obtained from estimating Eq. (2). We follow Alizadeh et al. (2002) and estimate stochastic volatility as the difference between the log of the daily high ask price and the log of the daily low bid price. We also examine a simple approximation of the noisiness of prices, which captures the large transitory price movements intraday (Blau et al. 2017). When an open price is greater than the closing price, Noise is the sum of the difference between the intraday high price less the open price and the closing price less the intraday low price. When the closing price is greater than the open price, Noise is the sum of the difference between the intraday high price less the closing price and the opening price less than the intraday low price. In both cases, these differences are scaled by the midpoint between the open price and the closing price. Table 2 shows that the average daily volatility is $1.21 \%$ based on the $\operatorname{GARCH}(1,1)$ model and $1.44 \%$ based on the range-based estimation. For treatment stocks, the average daily noisiness in prices is $0.71 \%$.

Throughout the multivariate analysis, we also use several control variables. Price is the closing CRSP price and $M C A P$ is the closing market capitalization for each stock (in \$billion). Turnover is the percentage of shares outstanding that are traded on a particular day. The average treatment stock has a closing price of $\$ 88.74$, a market capitalization of $\$ 131.29$ billion, and a daily share turnover of $0.64 \%$.

\section{Empirical Results}

This section presents the results of our empirical analysis. We conduct a host of multivariate tests using pooled stockday observations. In these tests, we use a difference-in-difference approach to compare the change in market quality surrounding the STOCK Act amendment for the treatment group, relative to the control group.

\section{The Effect of the STOCK Act Amendment on Transactions Costs}

In this subsection, we analyze the effect of the STOCK Act amendment on equity trading costs. Specifically, we estimate the following regression equation on pooled stock-day observations for the 41 days surrounding the amendment to the STOCK Act on April 15, 2013:

$$
\begin{aligned}
\operatorname{Ln}_{\left(\text {Transactions Costs }_{i, t}\right)=} & \alpha+\delta_{t}+\gamma_{i}+\beta_{1} \text { After }_{t} \\
& +\beta_{2} \text { Congress }_{i}+\beta_{3} \text { After }_{t} \\
& \times \text { Congress }_{i}+\beta_{4} \operatorname{Ln}\left(\text { Price }_{i, t}\right) \\
& +\beta_{5} \operatorname{Ln}\left(\text { MCAP }_{i, t}\right) \\
& +\beta_{6} \operatorname{Ln}(\text { Turnover })+\varepsilon_{i, t},
\end{aligned}
$$

where the dependent variable is the natural log of one of two trading cost measures: Dollar Effective Spread or Relative Effective Spread. These measures are defined in the previous section. We include the following as independent variables in Eq. (3): After is an indicator variable equal to one if the 
Table 3 Transactions costs surrounding the STOCK Act amendment

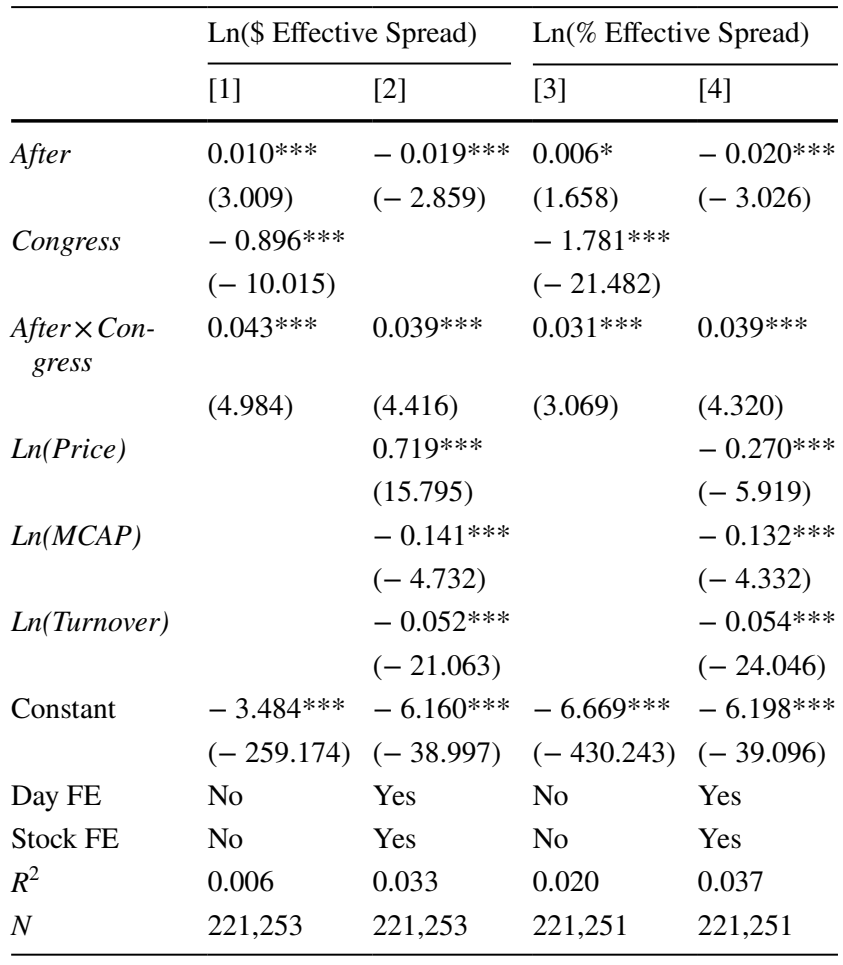

The table reports the results from estimating the following equation using pooled stock-day observations for the 41 days surrounding the STOCK Act Amendment on April 15, 2013:

Ln $\left(\right.$ TransactionsCosts $\left._{i, t}\right)=\alpha+\delta_{t}+\gamma_{i}+\beta_{1}$ After $_{t}+\beta_{2}$ Congress $_{i}+\beta_{3}$ After $_{t}$ $\times$ Congress $_{i}+\beta_{4} \operatorname{Ln}\left(\right.$ Price $\left._{i, t}\right)+\beta_{5} \operatorname{Ln}\left(M C A P_{i, t}\right)+\beta_{6} \operatorname{Ln}($ Turnover $)+\varepsilon_{i, t}$,

where the dependent variable is set to one of two trading cost measures: Ln(\$ Effective Spread) or Ln(\% Effective Spread). \$ Effective Spread on the $k$ th trade is defined as: $2 D_{k}\left(P_{k}-M_{k}\right)$, where $D_{k}$ is an indicator variable that equals +1 if the $k$ th trade is a buy and -1 if the $k$ th trade is a sell (according to Lee and Ready 1991), $P_{k}$ is the price of the $k$ th trade, and $M_{k}$ is the midpoint of the NBBO quotes assigned to the $k$ th trade. \% Effective Spread is the dollar effective spread scaled by the NBBO midpoint. After is an indicator variable equal to one if the stock/day observation takes place after April 15, 2013, and zero otherwise. Congress equals unity if the stock is one of the 49 securities held most by Congress (see Table 1) and zero for all other CRSP securities. We include the following control variables: $\operatorname{Ln}$ (Price) is the natural log of the average daily closing price. $\operatorname{Ln}(M C A P)$ is the natural $\log$ of market capitalization, or price times shares outstanding. Ln(Turnover) is the natural log of the daily number of shares traded over shares outstanding. We also include day fixed effects $\left(\delta_{t}\right)$ and stock fixed effects $\left(\gamma_{i}\right) . T$-statistics are reported in parentheses obtained from robust standard errors clustered at the stock level

$*, * *, * * *$ denote statistical significance at the $0.01,0.05$, and 0.10 levels, respectively.

stock-day observation takes place after April 15, 2013, and zero otherwise. ${ }^{13}$ Congress equals unity if the stock is one

\footnotetext{
13 To avoid violating the full rank condition required for consistent estimates, we drop a random day during the sample period in order to include both day fixed effects and the indicator variable After.
}

of the 49 securities held most by Congress (see Table 1) and zero for all other CRSP securities. We include the following control variables: $\operatorname{Ln}($ Price $)$ is the natural log of the average daily closing price. $\operatorname{Ln}(M C A P)$ is the natural log of market capitalization, or price times shares outstanding. $\operatorname{Ln}$ (Turnover) is the natural $\log$ of the daily number of shares traded over shares outstanding. In some specifications, we also include day fixed effects $\left(\delta_{t}\right)$ and stock fixed effects $\left(\gamma_{i}\right)$.

We report the estimated coefficients for various specifications of Eq. (3) in Table 3, with $t$-statistics in parentheses. We note that the $t$-statistics here, and those that follow, are obtained from robust (White 1980) standard errors clustered at the stock level. We find positive coefficients on the interaction term in each model specification, which are significant at the 0.01 level. In the first two columns of Table 3, we examine the average dollar effective spread surrounding the amendment to the STOCK Act. In the simplified OLS model specification (column [1]), we find that the average dollar effective spread widens by 4.3 percentage points for stocks held most by Congress (relative to control stocks) after the amendment. In the fixed-effects model specification (column [2]), we show that the average dollar effective spread widens by 3.9 percentage points for treatment stocks, compared to control stocks, post-amendment.

In the last two columns of Table 3, we analyze relative effective spreads around the STOCK Act amendment. In the simple OLS model (column [3]), we find that the average relative effective spread increases by 3.1 percentage points for stocks held most by Congress, compared to stocks in the control group, after the amendment. In the full fixed-effects model specification (column [4]), we find that the average relative effective spread increases by 3.9 percentage points for treatment stocks, compared to control stocks, ex-post.

The results in Table 3 show a significant increase in the average cost of a round-trip trade for stocks held most by Congress, relative to the market, after the STOCK Act amendment that removed the trade disclosure requirement for staff members of Congress. Therefore, consistent with the theoretical models of Copeland and Galai (1983), Kyle (1985), and Glosten and Milgrom (1985), relaxing constraints on governmental insider trading leads to an increase in the bid-ask spread.

\section{The Effect of the STOCK Act Amendment on Market Depth}

Next, we examine the stock market depth surrounding the STOCK Act amendment. To do so, we estimate the following fixed-effects regression equation on pooled stock-day observations for the 41 days surrounding the STOCK Act amendment on April 15, 2013: 
Table 4 Depth surrounding the STOCK Act amendment

\begin{tabular}{|c|c|c|c|c|c|c|}
\hline & \multicolumn{2}{|c|}{ Ln(Quoted Depth) } & \multicolumn{2}{|c|}{ Ln(Ask Depth) } & \multicolumn{2}{|c|}{ Ln(Bid Depth) } \\
\hline & {$[1]$} & {$[2]$} & {$[3]$} & {$[4]$} & {$[5]$} & {$[6]$} \\
\hline After & $\begin{array}{l}-0.011 * * \\
(-2.472)\end{array}$ & $\begin{array}{l}-0.058 * * * \\
(-6.761)\end{array}$ & $\begin{array}{l}-0.005 \\
(-0.954)\end{array}$ & $\begin{array}{l}-0.035^{* * *} \\
(-3.286)\end{array}$ & $\begin{array}{l}-0.019 * * * \\
(-3.942)\end{array}$ & $\begin{array}{l}-0.072 * * * \\
(-7.326)\end{array}$ \\
\hline Congress & $\begin{array}{l}1.539 * * * \\
(6.333)\end{array}$ & & $\begin{array}{l}1.561 * * * \\
(6.401)\end{array}$ & & $\begin{array}{l}1.634 * * * \\
(6.732)\end{array}$ & \\
\hline After $\times$ Congress & $\begin{array}{l}-0.178 * * * \\
(-7.761)\end{array}$ & $\begin{array}{l}-0.173 * * * \\
(-7.959)\end{array}$ & $\begin{array}{l}-0.187 * * * \\
(-7.859)\end{array}$ & $\begin{array}{l}-0.181 * * * \\
(-7.918)\end{array}$ & $\begin{array}{l}-0.168 * * * \\
(-7.068)\end{array}$ & $\begin{array}{l}-0.164 * * * \\
(-7.397)\end{array}$ \\
\hline Ln(Price) & & $\begin{array}{l}-0.831 * * * \\
(-7.389)\end{array}$ & & $\begin{array}{l}-0.674 * * * \\
(-5.486)\end{array}$ & & $\begin{array}{l}-1.006^{* * *} \\
(-9.461)\end{array}$ \\
\hline $\operatorname{Ln}(M C A P)$ & & $\begin{array}{l}0.155 * * * \\
(2.775)\end{array}$ & & $\begin{array}{l}0.138 * * \\
(2.265)\end{array}$ & & $\begin{array}{l}0.193 * * * \\
(3.445)\end{array}$ \\
\hline Ln(Turnover) & & $\begin{array}{l}0.096 * * * \\
(32.295)\end{array}$ & & $\begin{array}{l}0.099 * * * \\
(29.755)\end{array}$ & & $\begin{array}{l}0.096 * * * \\
(30.019)\end{array}$ \\
\hline Constant & $\begin{array}{l}7.630 * * * \\
(452.526)\end{array}$ & $\begin{array}{l}10.976 * * * \\
(28.554)\end{array}$ & $\begin{array}{l}6.908 * * * \\
(400.097)\end{array}$ & $\begin{array}{l}9.743 * * * \\
(23.215)\end{array}$ & $\begin{array}{l}6.841 * * * \\
(417.824)\end{array}$ & $\begin{array}{l}10.770^{* * *} \\
(29.600)\end{array}$ \\
\hline Day FE & No & Yes & No & Yes & No & Yes \\
\hline Stock FE & No & Yes & No & Yes & No & Yes \\
\hline$R^{2}$ & 0.011 & 0.052 & 0.011 & 0.035 & 0.013 & 0.038 \\
\hline$N$ & 221,265 & 221,265 & 221,265 & 221,265 & 221,265 & 221,265 \\
\hline
\end{tabular}

The table reports the results from estimating the following equation using pooled stock-day observations for the 41 days surrounding the STOCK Act Amendment on April 15, 2013:

Ln $\left(\right.$ Depth $\left._{i, t}\right)=\alpha+\delta_{t}+\gamma_{i}+\beta_{1}$ After $_{t}+\beta_{2}$ Congress $_{i}+\beta_{3}$ After $_{t} \times$ Congress $_{i}+\beta_{4} L n\left(\right.$ Price $\left._{i, t}\right)+\beta_{5} L n\left(\right.$ MCAP $\left._{i, t}\right)+\beta_{6}$ Ln $\left._{\text {(Turnover }}\right)+\varepsilon_{i, t}$, where the dependent variable is set to one of three depth measures: Ln(Quoted Depth), Ln(Ask Depth), or Ln(Bid Depth). Quoted Depth is the number of shares available at the NBBO at the time of the $k$ th trade. Ask Depth is the number of shares available at the NBO at the time of the kth trade. Bid Depth is the number of shares available at the NBB at the time of the $k$ th trade. After is an indicator variable equal to one if the stock/day observation takes place after April 15, 2013, and zero otherwise. Congress equals unity if the stock is one of the 49 securities held most by Congress (see Table 1) and zero for all other CRSP securities. We include the following control variables: Ln(Price) is the natural log of the average daily closing price. $\operatorname{Ln}(M C A P)$ is the natural $\log$ of market capitalization, or price times shares outstanding. Ln(Turnover) is the natural $\log$ of the daily number of shares traded over shares outstanding. We also include day fixed effects $\left(\delta_{t}\right)$ and stock fixed effects $\left(\gamma_{i}\right) . T$-statistics are reported in parentheses obtained from robust standard errors clustered at the stock level

$*, * *, * * *$ denote statistical significance at the $0.01,0.05$, and 0.10 levels, respectively

$$
\begin{aligned}
\operatorname{Ln}_{\left(\text {Depth }_{i, t}\right)=} & \alpha+\delta_{t}+\gamma_{i}+\beta_{1} \text { After }_{t}+\beta_{2} \text { Congress }_{i} \\
& +\beta_{3} \text { After }_{t} \times \text { Congress }_{i} \\
& \left.+\beta_{4} \text { Ln }_{\text {Price }}\right)+\beta_{5} \operatorname{Ln}\left(\text { MCAP }_{i, t}\right) \\
& \left.+\beta_{6} \text { Ln }_{\text {Turnover }}\right)+\varepsilon_{i, t}
\end{aligned}
$$

where the dependent variable is the natural log of one of three depth measures for stock $i$ on day $t$. Quoted Depth is the total number of shares available to trade at the National Best Bid and Offer (NBBO). We then separate shares available on the bid and ask sides of the order book. Ask Depth is the total number of shares available the National Best Offer (NBO), while Bid Depth is the total number of shares available at the National Best Bid (NBB). The independent variables have previously been defined.

We report the estimated coefficients from Eq. (4) in Table 4 with $t$-statistics in parentheses. In the first two columns of Table 4, we analyze the total depth at the NBBO surrounding the STOCK Act amendment. In the simple OLS model (column [1]), we show a significant decrease in quoted depth by 17.8 percentage points for stocks held most by Congress, relative to control stocks, after the amendment. Even after controlling for firm and day fixed effects, we continue to find a significant decline in quoted depth for stocks held most by Congress, compared to the market, following the amendment. Specifically, the coefficient on the interaction term in column [2] is -0.173 , which is significant at the 0.01 level. In economic terms, the quoted depth decreases by an average of 17.3 percentage points for treatment stocks, compared to control stocks, after the amendment.

In the third and fourth columns of Table 4, we examine depth available at the NBO around the STOCK Act Amendment. In the simplified model specification (column [3]), we find a decline in the average ask depth by 18.7 percentage 
points for stocks held most by Congress, relative to the market, post-amendment. We continue to find a significant decrease in average depth available on the offer side of the NBBO after controlling for stock and day fixed effects. The results in column [4] show that the average ask depth decreases by 18.1 percentage points for treatment stocks, compared to control stocks, after the amendment. ${ }^{14}$

In the final two columns of Table 4, we analyze the average depth available at the NBB surrounding the STOCK Act amendment. We show a significant decrease in the average bid depth for stocks held most by Congress, compared to the market, after the amendment. Specifically, in the full fixed-effects model specification (column [6]), we show a significant 16.4 percentage point decrease in average depth available at the NBB for treatment stocks vis-à-vis control stocks post-amendment.

The results in Table 4 show a significant depletion of top-of-book depth for stocks held most by Congress, relative to the market, after the STOCK Act amendment. In other words, our results provide strong evidence of a decrease in liquidity provision surrounding the amendment to the STOCK Act, which relaxed the insider trading disclosure requirements for certain government employees. This suggests that an increase in insider trading is associated with a significant decrease in depth available at the top of the limit order book. Orders that exceed the depth available at the NBBO will cost more to trade, as they must walk the limit order book after exhausting all the shares available at the inside quotes (Jones and Lipson 1999). Thus, our results suggest that allowing insider trading by Congressional staffers reduces market depth.

\section{The Effect of the STOCK Act Amendment on Adverse Selection Costs}

In this subsection, we analyze whether or not the STOCK Act amendment affected the level of asymmetric information in the equity market. Following the microstructure literature (e.g. Van Ness et al. 2001; Hendershott et al. 2011), we decompose the bid-ask spread into the price impact component, which captures the gross losses to liquidity demanders from adverse selection. As an alternative low-frequency proxy of adverse selection, we estimate Amihud's (2002) illiquidity measure. The 5-min price impact and Amihud

\footnotetext{
${ }^{14}$ We do not find that the decline in average depth at the NBO is more significant than the decline in average depth at the NBB. Therefore, we fail to find significant order imbalance surrounding the STOCK Act amendment for treatment stocks, relative to controls stocks.
}

(2002) illiquidity measures have been defined in the preceding section.

To analyze the effect of insider regulation laws on information asymmetry, we estimate specifications of the following equation on pooled stock-day observations in the 41 days surrounding the amendment to the STOCK Act on April 15, 2013 :

$$
\begin{aligned}
\text { Ln }_{\left(\text {Adverse Selection }_{i, t}\right)=} & \alpha+\delta_{t}+\gamma_{i}+\beta_{1} \text { After }_{t}+\beta_{2} \text { Congress }_{i} \\
& +\beta_{3} \text { After }_{t} \times \text { Congress }_{i} \\
& +\beta_{4} \operatorname{Ln}\left(\text { Price }_{i, t}\right)+\beta_{5} \operatorname{Ln}\left(\text { MCAP }_{i, t}\right) \\
& +\beta_{6} \operatorname{Ln}(\text { Turnover })+\varepsilon_{i, t},
\end{aligned}
$$

where the dependent variable is either the natural log of the average intraday 5-min price impact or the natural log of the daily Amihud (2002) illiquidity. The independent variables have been defined previously. We report the estimated coefficients from Eq. (5) in Table 5 with $t$-statistics in parentheses.

In the first two columns of Table 5, we examine the dollar price impact surrounding the STOCK Act amendment. In both the simplified and full model specifications, we find that the average dollar price impact significantly increases for stocks held most by Congress, relative to control stocks, after the amendment. In economic terms, the average dollar price impact increases by 7.6 percentage points for treatment stocks, compared to the broader market, post-amendment. These results hold after controlling for firm-specific characteristics, stock fixed effects, and time fixed effects.

In the second two columns of Table 5, we analyze the relative price impact around the amendment to the STOCK Act. In the simplified model (column [3]), we find that the average relative price impact increases by 5.4 percentage points for stock held most by Congress, compared to control stocks, following the amendment. In the full model specification (column [4]), we find that the average relative price impact increases by 7 percentage points for treatment stocks vis-à-vis control stocks after the amendment.

In the final two columns of Table 5, we examine the change in Amihud's (2002) illiquidity measure following the amendment to the STOCK Act. We find insignificant coefficients on the interaction term in both model specifications. These results indicate that average illiquidity in stocks held most by Congress, compared to control stocks, remains relatively stable surrounding the amendment to the STOCK Act. We note that Amihud's (2002) illiquidity might be capturing other aspects of liquidity different from adverse selection.

The results in columns [1] through [4] of Table 5 provide compelling evidence that adverse selection costs increase in stocks held most by Congress, relative to the market, after the amendment. Thus, our results suggest that the level of asymmetric information increases in treatment stocks, compared to control stocks, after the relaxation of disclosure requirements for Congressional staff members. 
Table 5 Adverse selection costs surrounding the STOCK Act amendment

\begin{tabular}{|c|c|c|c|c|c|c|}
\hline & \multicolumn{2}{|c|}{$\operatorname{Ln}(\$$ Price Impact $)$} & \multicolumn{2}{|c|}{ Ln(\% Price Impact) } & \multicolumn{2}{|l|}{ Ln(Illiq) } \\
\hline & {$[1]$} & {$[2]$} & {$[3]$} & {$[4]$} & {$[5]$} & [6] \\
\hline After & $\begin{array}{l}-0.019 * * * \\
(-2.738)\end{array}$ & $\begin{array}{l}-0.055 * * \\
(-2.015)\end{array}$ & $\begin{array}{l}-0.013 * * \\
(-2.228)\end{array}$ & $\begin{array}{l}-0.074 * * * \\
(-4.089)\end{array}$ & $\begin{array}{l}0.145^{* * *} \\
(16.414)\end{array}$ & $\begin{array}{l}0.060 * * * \\
(2.817)\end{array}$ \\
\hline Congress & $\begin{array}{l}-0.616^{* * * *} \\
(-7.520)\end{array}$ & & $\begin{array}{l}-1.512 * * * \\
(-17.649)\end{array}$ & & $\begin{array}{l}-5.381 * * * \\
(-30.960)\end{array}$ & \\
\hline After $\times$ Congress & $\begin{array}{l}0.076 * * \\
(2.355)\end{array}$ & $\begin{array}{l}0.076 * * \\
(2.453)\end{array}$ & $\begin{array}{l}0.054 * \\
(1.799)\end{array}$ & $\begin{array}{l}0.070 * * \\
(2.269)\end{array}$ & $\begin{array}{l}0.037 \\
(0.820)\end{array}$ & $\begin{array}{l}0.060 \\
(1.395)\end{array}$ \\
\hline Ln(Price $)$ & & $\begin{array}{l}0.693 * * * \\
(9.189)\end{array}$ & & $\begin{array}{l}-0.256 * * * \\
(-3.598)\end{array}$ & & $\begin{array}{l}-0.124 * \\
(-1.747)\end{array}$ \\
\hline $\operatorname{Ln}(M C A P)$ & & $\begin{array}{l}-0.140 * * \\
(-2.416)\end{array}$ & & $\begin{array}{l}-0.103 * * \\
(-2.175)\end{array}$ & & $\begin{array}{l}-1.087 * * * \\
(-13.767)\end{array}$ \\
\hline Ln(Turnover) & & $\begin{array}{l}0.104 * * * \\
(12.665)\end{array}$ & & $\begin{array}{l}0.079 * * * \\
(14.757)\end{array}$ & & $\begin{array}{l}-0.735 * * * \\
(-125.546)\end{array}$ \\
\hline Constant & $\begin{array}{l}-4.560 * * * \\
(-356.982)\end{array}$ & $\begin{array}{l}-6.315^{* * *} \\
(-24.448)\end{array}$ & $\begin{array}{l}-7.725 * * * \\
(-570.568)\end{array}$ & $\begin{array}{l}-6.554 * * * \\
(-27.208)\end{array}$ & $\begin{array}{l}-6.015 * * * \\
(-177.591)\end{array}$ & $\begin{array}{l}-10.418 * * * \\
(-39.255)\end{array}$ \\
\hline Day FE & No & Yes & No & Yes & No & Yes \\
\hline Stock FE & No & Yes & No & Yes & No & Yes \\
\hline$R^{2}$ & 0.001 & 0.006 & 0.012 & 0.010 & 0.034 & 0.241 \\
\hline$N$ & 197,715 & 197,715 & 197,757 & 197,757 & 216,097 & 216,097 \\
\hline
\end{tabular}

The table reports the results from estimating the following equation using pooled stock-day observations for the 41 days surrounding the STOCK Act Amendment on April 15, 2013:

Ln $\left(\right.$ AdverseSelectionCosts $\left._{i, t}\right)=\alpha+\delta_{t}+\gamma_{i}+\beta_{1}$ After $_{t}+\beta_{2}$ Congress $_{i}+\beta_{3}$ After $_{t} \times$ Congress $_{i}+\beta_{4}$ Ln $\left._{\left(\text {Price }_{i, t}\right.}\right)$ $+\beta_{5} \operatorname{Ln}\left(\right.$ MCAP $\left._{i, t}\right)+\beta_{6} \operatorname{Ln}($ Turnover $)+\varepsilon_{i, t}$

where the dependent variable is set to one of three measures of adverse selection costs: $\operatorname{Ln}(\$$ Price Impact), Ln(\% Price Impact), or Ln(Illiq). \$ Price Impact on the $k$ th trade is defined as: $2 D_{k}\left(M_{k+5}-M_{k}\right)$, where $D_{k}$ is an indicator variable that equals +1 if the $k$ th trade is a buy and -1 if the $k$ th trade is a sell (according to Lee and Ready 1991), and $M_{k+5}$ is the NBBO midpoint 5-min after the midpoint $M_{k}$. \% Price Impact is the dollar price impact scaled by the NBBO midpoint. Illiq is Amihud's (2002) illiquidity measure defined as the absolute value of daily return divided by dollar volume, scaled by $10^{6}$. After is an indicator variable equal to one if the stock/day observation takes place after April 15, 2013, and zero otherwise. Congress equals unity if the stock is one of the 49 securities held most by Congress (see Table 1) and zero for all other CRSP securities. We include the following control variables: Ln(Price) is the natural log of the average daily closing price. $\operatorname{Ln}(M C A P)$ is the natural $\log$ of market capitalization, or price times shares outstanding. Ln(Turnover) is the natural log of the daily number of shares traded over shares outstanding. We also include day fixed effects $\left(\delta_{t}\right)$ and stock fixed effects $\left(\gamma_{i}\right)$. T-statistics are reported in parentheses obtained from robust standard errors clustered at the stock level

$*, * *, * * *$ denote statistical significance at the $0.01,0.05$, and 0.10 levels, respectively

\section{The Effect of the STOCK Act Amendment on Price Stability}

In this subsection, we replicate our previous analyses but examine three measures of price stability. We estimate specifications of the following regression equation using pooled stock-day observations in the 41 days surrounding the amendment to the STOCK Act on April 15, 2013:

$$
\begin{aligned}
{\text { Ln }\left(\text { Price Stability }_{i, t}\right)=} & \alpha+\delta_{t}+\gamma_{i}+\beta_{1} \text { After }_{t}+\beta_{2} \text { Congress }_{i} \\
& \left.+\beta_{3} \text { After }_{t} \times \text { Congress }_{i}+\beta_{4} \text { Ln }_{\text {Price }} \text { Prt }_{i, t}\right) \\
& +\beta_{5} \operatorname{Ln}\left(M C A P_{i, t}\right)+\beta_{6} \text { Ln }(\text { Turnover })+\varepsilon_{i, t},
\end{aligned}
$$

where the dependent variable is the natural log of one of three price stability proxies: Garch $(1,1)$, Range Volatility, or Noise. The variable descriptions are found in the data section and the table header. We report the estimated coefficients from Eq. (6) in Table 6, with $t$-statistics in parentheses.

In the first two columns of Table 6 , we examine return volatility measured from a Garch $(1,1)$ model surrounding the STOCK Act amendment. We find that in both the simple and full model specifications, average volatility is significantly higher for stocks held most by Congress, compared to control stocks, in the post-event period. In the fixedeffects model specification (column [2]), we find that the average Garch $(1,1)$ volatility increases by 3.2 percentage 
Table 6 Price stability surrounding the STOCK Act amendment

\begin{tabular}{|c|c|c|c|c|c|c|}
\hline & \multicolumn{2}{|c|}{ Ln(Garch Volatility) } & \multicolumn{2}{|c|}{ Ln(Range Volatility) } & \multicolumn{2}{|l|}{ Ln(Noise) } \\
\hline & {$[1]$} & {$[2]$} & {$[3]$} & [4] & {$[5]$} & [6] \\
\hline After & $\begin{array}{l}0.026 * * * \\
(8.635)\end{array}$ & $\begin{array}{l}-0.058^{* * *} \\
(-18.526)\end{array}$ & $\begin{array}{l}0.051 * * * \\
(12.275)\end{array}$ & $\begin{array}{l}0.035^{* * * *} \\
(3.280)\end{array}$ & $\begin{array}{l}0.021 * * * \\
(4.352)\end{array}$ & $\begin{array}{l}0.040 * * \\
(2.502)\end{array}$ \\
\hline Congress & $\begin{array}{l}-0.127 * * * \\
(-13.922)\end{array}$ & & $\begin{array}{l}-0.146^{* * *} \\
(-4.043)\end{array}$ & & $\begin{array}{l}-0.167 * * * \\
(-3.749)\end{array}$ & \\
\hline After $\times$ Congress & $\begin{array}{l}0.028 * * \\
(2.143)\end{array}$ & $\begin{array}{l}0.032 * \\
(1.771)\end{array}$ & $\begin{array}{l}0.084 * * * \\
(3.829)\end{array}$ & $\begin{array}{l}0.083 * * * \\
(4.313)\end{array}$ & $\begin{array}{l}0.114 * * * \\
(3.261)\end{array}$ & $\begin{array}{l}0.116 * * * \\
(3.420)\end{array}$ \\
\hline Ln(Price) & & $\begin{array}{l}-0.024 \\
(-1.516)\end{array}$ & & $\begin{array}{l}-0.280 * * * \\
(-6.037)\end{array}$ & & $\begin{array}{l}-0.401 * * * \\
(-7.400)\end{array}$ \\
\hline $\operatorname{Ln}(M C A P)$ & & $\begin{array}{l}-0.016 \\
(-1.498)\end{array}$ & & $\begin{array}{l}0.084 * * \\
(2.313)\end{array}$ & & $\begin{array}{l}0.153 * * * \\
(3.756)\end{array}$ \\
\hline Ln(Turnover) & & $\begin{array}{l}0.023 * * * \\
(19.971)\end{array}$ & & $\begin{array}{l}0.279 * * * \\
(61.299)\end{array}$ & & $\begin{array}{l}0.260 * * * \\
(60.578)\end{array}$ \\
\hline Constant & $\begin{array}{l}-4.327 * * * \\
(-2012.964)\end{array}$ & $\begin{array}{l}-4.091 * * * \\
(-74.660)\end{array}$ & $\begin{array}{l}-4.195 * * * \\
(-451.989)\end{array}$ & $\begin{array}{l}-1.915^{* * *} \\
(-11.863)\end{array}$ & $\begin{array}{l}-4.952 * * * \\
(-520.834)\end{array}$ & $\begin{array}{l}-2.339 * * * \\
(-12.629)\end{array}$ \\
\hline Day FE & No & Yes & No & Yes & No & Yes \\
\hline Stock FE & No & Yes & No & Yes & No & Yes \\
\hline$R^{2}$ & 0.001 & 0.044 & 0.001 & 0.166 & 0.000 & 0.065 \\
\hline$N$ & 221,193 & 221,193 & 217,536 & 217,536 & 201,865 & 201,865 \\
\hline
\end{tabular}

The table reports the results from estimating the following equation using pooled stock-day observations for the 41 days surrounding the STOCK Act Amendment on April 15, 2013:

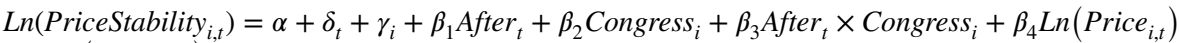
$+\beta_{5} \operatorname{Ln}\left(\right.$ MCAP $\left._{i, t}\right)+\beta_{6} \operatorname{Ln}$ (Turnover $)+\varepsilon_{i, t}$,

where the dependent variable is set to one of three measures of price stability: $\operatorname{Ln}(\operatorname{Garch}(1,1)), \operatorname{Ln}($ Range Volatility), or Ln(Noise). Garch Volatility is the volatility of stock returns obtained by fitting returns to a Garch $(1,1)$ model. Range Volatility is measured as the log of the daily high ask price minus the log of the daily low bid price. When an open price is greater (less) than the closing price, Noise is the sum of the difference between the intraday high price less the open price (closing price) and the closing price (opening price) less the intraday low price, scaled by the midpoint between the open price and the closing price. After is an indicator variable equal to one if the stock/day observation takes place after April 15, 2013, and zero otherwise. Congress equals unity if the stock is one of the 49 securities held most by Congress (see Table 1) and zero for all other CRSP securities. We include as control variables: Ln(Price) is the natural $\log$ of the average daily closing price. $\operatorname{Ln}(M C A P)$ is the natural $\log$ of market capitalization, or price times shares outstanding. Ln(Turnover) is the natural log of the daily number of shares traded over shares outstanding. We also include day fixed effects $\left(\delta_{t}\right)$ and stock fixed effects $\left(\gamma_{i}\right)$. T-statistics are reported in parentheses obtained from robust standard errors clustered at the stock level

$*, * *, * * *$ denote statistical significance at the $0.01,0.05$, and 0.10 levels, respectively points for treatment stocks, relative to control stocks, after the amendment.

In columns [3] and [4] of Table 6, we analyze price stability as measured by the daily range around the STOCK Act amendment. We find positive coefficients on the interaction term in both model specifications that are significant at the 0.01 level. This suggests that average range-based volatility increases for treatment stocks vis-à-vis control stocks around the amendment. Specifically, we find that the average range-based volatility increases between 8.3 and 8.4 percentage points for stocks held most by Congress, relative to the market, after the amendment.

In the final two columns of Table 6, we examine the noisiness in prices around the amendment to the STOCK act. The results in column [5] show an increase in noise by 11.4 percentage points for stocks held most by Congress, 
compared to the broader market, after the act is amended. We find similar results in column [6] controlling for both stock and day fixed effects. For instance, the coefficient on the interaction term is 0.116 , which is significant at the 0.01 level. This suggests that holding other factors constant, the noise in the prices of stocks held most by Congress, relative to the market, increase by 11.6 percentage points after the amendment. ${ }^{15}$

\section{A Discussion on the Ethical Implications of Our Results}

Aside from the economic costs and benefits associated with insider trading, the literature has offered several debates regarding the ethical considerations of insider trading. In this subsection, we attempt to place our findings into this literature. It is uncertain whether or not the literature has even reached a consensus on the ethics of insider trading. On one hand, Werhane $(1989,1991)$ and Ma and Sun (1998) attempt to provide the structure for the ethical arguments against insider trading. On the other hand, Martin and Peterson (1991) and Snoeyenbos and Smith (2000) argue that, in a free-market, insider trading can still be permitted despite the asymmetry in the information held by those that trade in financial markets. In a recent study, Smith and Block (2016) suggest that insider trading should not be prohibited and that such trading is good for markets. The authors specifically point to Manne's (1966) study and suggest that the improved price stability associated with insider trading is "undisputed".

Moore (1990) attempts to disentangle which types of insider trading should be considered unethical (see also Engelen and Liedekerke 2007 and McGee 2008). The author argues that the traditional justifications (i.e. unfairness, property rights, and harm) for prohibiting insider trading are insufficient in isolation. The author posits that the strongest argument against insider trading is that it can undermine the fiduciary relationships between the firm, its employees, and shareholders. While compelling, this argument does not

\footnotetext{
$\overline{15}$ We conduct a series of robustness tests. First, we use a different approach than those discussed above by using as the dependent variables, the difference between the market quality measures for the treated stocks and the average market quality measures for the control sample stocks. Results from these unreported tests are qualitatively similar to those reported in Tables 3, 4, 5 and 6. Second, we replicate the multivariate results using market quality measures without taking the natural logs of the dependent variables. Again, results are qualitatively similar. Finally, we extend our multivariate results by including an indicator capturing NASDAQ listed stocks and a triple difference that attempts to determine whether our results are driven by listing on a particular exchange. Here, we do not find a reliable triple difference estimator.
}

account for the type of insider trading that we explore in this study. Because government officials are not corporate insiders, nor employees, they do not hold the same fiduciary responsibility discussed in Moore (1990).

The question then becomes, "What is to be done about noncorporate insider trading?" Should this type of insider trading be permitted? Corporate insider trading has been restricted since the passage of the Securities and Exchange Act of 1934, while laws to restrict government insider trading has only been discussed over the last decade. Perhaps the same arguments in Moore (1990) can be extended to account for insider trading by government officials. That is, elected officials, and those employed by the government, have a fiduciary duty to the general public as well as to the office that they hold. In the Moore (1990) framework, our results suggest that the practice of insider trading by government officials may be deemed unfair (outside investors cannot possibly obtain similar information), harmful (higher trading costs and greater volatility for ordinary investors), and in certain situations a violation of the firm's property rights (information is not owned by government officials). Furthermore, insider trading by government officials may ultimately create distrust between shareholders (liquidity providers widen spreads to compensate for trading with insiders) and also between the firm and its stakeholders. Therefore, trading by non-corporate insiders has the potential to violate all four ethical arguments proposed by Moore (1990), which altogether, might merit legal restriction.

\section{Concluding Remarks}

This paper examines the effect of perceived non-corporate insider trading on the quality of financial markets. In particular, we examine the quality and stability of financial markets surrounding an arguably exogenous shock to the relaxation of non-corporate insider trading. In April 2013, a bill by the U.S. Senate quickly made its way through Congress and was signed into law overhauling the STOCK Act, which initially restricted insider trading by members and employees of Congress and other branches of the federal government. In an unexpected event, the act was amended to relax the restrictions on employees of the federal government but remained in effect for elected officials. Using this amendment as a natural experiment, we test whether liquidity and volatility meaningfully change in response to this event. In our analysis, we use as a treatment group, the stocks that are most widely held by Congress, and a control group, all other securities.

Results from our tests show that, relative to the control sample, bid-ask spreads increase for treatment stocks while quoted depth decreases in response to the amendment of the STOCK Act. We also find some evidence that price impact, which we use to approximate adverse selection costs, increases for the treated stocks vis-à-vis the control stocks during the period immediately 
following the amendment. When examining the stability of stock prices, we find that, relative to the control sample, the treatment stocks experience a significant increase in volatility during the post-amendment period. To the extent that our natural experiment represents an exogenous shock to the relaxation of non-corporate insider trading, these findings suggest that the presence of perceived insider trading seems to destabilize stock prices and harm market quality in a meaningful way.

Moore (1990) argues that traditional justifications for the prohibition of insider trading, such as fairness, protection of property rights, and harm, are insufficient in isolation. Furthermore, the author contends that the strongest argument to legislate insider trading lies in the protection of the legal and moral fiduciary relationships between the firm, its employees, and shareholders. Our analysis questions what is to be done about insider trading by non-corporate insiders. Are the justifications sufficient? Or should insider trading by non-corporate insiders be permitted? The observed increase in trading costs, adverse selection costs, and volatility around the relaxation of insider trading laws lend direct support for the unfairness, harmfulness, and distrust ethical arguments outlined above. Thus, it appears that more stringent restrictions on non-corporate insiders might be warranted.

\section{Compliance with Ethical Standards}

Conflict of interest The authors declare that they have no conflict of interest.

\section{References}

Ahmed, A. S., McAnally, M. L., Rasmussen, S., \& Weaver, C. D. (2010). How costly is the Sarbanes Oxley Act? Evidence on the effects of the Act on corporate profitability. Journal of Corporate Finance, 16(3), 352-369.

Alizadeh, S., Brandt, M. W., \& Diebold, F. X. (2002). Range-based estimation of stochastic volatility models. The Journal of Finance, 57(3), 1047-1091.

Allen, F., \& Gale, D. (1992). Stock-price manipulation. The Review of Financial Studies, 5(3), 503-529.

Amihud, Y. (2002). Illiquidity and stock returns: Cross-section and time-series effects. Journal of Financial Markets, 5(1), 31-56.

Ausubel, L. M. (1990). Insider trading in a rational expectations economy. The American Economic Review, 1, 1022-1041.

Barclay, M. J., \& Smith, C. W., Jr. (1988). Corporate payout policy: Cash dividends versus open-market repurchases. Journal of Financial Economics, 22(1), 61-82.

Benabou, R., \& Laroque, G. (1992). Using privileged information to manipulate markets: Insiders, gurus, and credibility. The Quarterly Journal of Economics, 107(3), 921-958.

Bettis, J. C., Coles, J. L., \& Lemmon, M. L. (2000). Corporate policies restricting trading by insiders. Journal of Financial Economics, 57(2), 191-220.

Bhattacharya, S., \& Nicodano, G. (2001). Insider trading, investment, and liquidity: A welfare analysis. The Journal of Finance, 56(3), 1141-1156.
Blau, B., Griffith, T., \& Whitby, R. (2017). Risk in noisy prices. Working Paper, Utah State University.

Brockman, P., \& Chung, D. Y. (2001). Managerial timing and corporate liquidity: Evidence from actual share repurchases. Journal of Financial Economics, 61(3), 417-448.

Brudney, V. (1979). Insiders, outsiders, and informational advantages under the federal securities laws. Harvard Law Review, 93, 322-376.

Copeland, T. E., \& Galai, D. (1983). Information effects on the bid-ask spread. The Journal of Finance, 38(5), 1457-1469.

$\mathrm{Du}$, J., \& Wei, S. J. (2004). Does insider trading raise market volatility? The Economic Journal, 114(498), 916-942.

Engelen, P. J., \& Van Liedekerke, L. (2007). The ethics of insider trading revisited. Journal of Business Ethics, 74(4), 497-507.

Glosten, L. R., \& Milgrom, P. R. (1985). Bid, ask and transaction prices in a specialist market with heterogeneously informed traders. Journal of Financial Economics, 14(1), 71-100.

Goyenko, R. Y., Holden, C. W., \& Trzcinka, C. A. (2009). Do liquidity measures measure liquidity? Journal of Financial Economics, 92(2), 153-181.

Hendershott, T., Jones, C. M., \& Menkveld, A. J. (2011). Does algorithmic trading improve liquidity? The Journal of Finance, 66(1), $1-33$.

Jeng, L. A., Metrick, A., \& Zeckhauser, R. (2003). Estimating the returns to insider trading: A performance-evaluation perspective. Review of Economics and Statistics, 85(2), 453-471.

Jones, C. M., \& Lipson, M. L. (1999). Execution costs of institutional equity orders. Journal of Financial Intermediation, 8(3), 123-140.

Kyle, A. S. (1985). Continuous auctions and insider trading. Econometrica: Journal of the Econometric Society, 53, 1315-1335.

Lee, C. M., \& Ready, M. J. (1991). Inferring trade direction from intraday data. The Journal of Finance, 46(2), 733-746.

Leland, H. E. (1992). Insider trading: Should it be prohibited? Journal of Political Economy, 100(4), 859-887.

Lin, J. C., \& Rozeff, M. S. (1995). The speed of adjustment of prices to private information: Empirical tests. Journal of Financial Research, 18(2), 143-156.

Ma, Y., \& Sun, H. L. (1998). Where should the line be drawn on insider trading ethics? Journal of Business Ethics, 17(1), 67-75.

Manne, H. G. (1966). Insider trading and the stock market. New York: Free Press.

Manove, M. (1989). The harm from insider trading and informed speculation. The Quarterly Journal of Economics, 104(4), 823-845.

Martin, D. W., \& Peterson, J. H. (1991). Insider trading revisited. Journal of Business Ethics, 10(1), 57-61.

McGee, R. W. (2008). Applying ethics to insider trading. Journal of Business Ethics, 77(2), 205-217.

Moore, J. (1990). What is really unethical about insider trading? Journal of Business Ethics, 9(3), 171-182.

Seyhun, H. N. (1992). The effectiveness of the insider-trading sanctions. The Journal of Law and Economics, 35(1), 149-182.

Smith, T., \& Block, W. E. (2016). The economics of insider trading: A free market perspective. Journal of Business Ethics, 139(1), 47-53.

Snoeyenbos, M., \& Smith, K. (2000). Ma and Sun on insider trading ethics. Journal of Business Ethics, 28(4), 361-363.

Van Ness, B. F., Van Ness, R. A., \& Warr, R. S. (2001). How well do adverse selection components measure adverse selection? Financial Management, 30(3), 77-98.

Werhane, P. H. (1989). The ethics of insider trading. Journal of Business Ethics, 8(11), 841-845.

Werhane, P. H. (1991). The indefensibility of insider trading. Journal of Business Ethics, 10(9), 729-731.

White, H. (1980). A heteroscedasticity-consistent covariance matrix estimator and a direct test for heteroscedasticity. Econometrica, $48,817-838$. 
Ziobrowski, A. J., Cheng, P., Boyd, J. W., \& Ziobrowski, B. J. (2004). Abnormal returns from the common stock investments of the US Senate. Journal of Financial and Quantitative Analysis, 39(4), 661-676.

Ziobrowski, A. J., Boyd, J. W., Cheng, P., \& Ziobrowski, B. J. (2011). Abnormal returns from the common stock investments of members of the US House of Representatives. Business and Politics, 13(1), 1-22.

Publisher's Note Springer Nature remains neutral with regard to jurisdictional claims in published maps and institutional affiliations. 